\title{
Preclinical diabetes mellitus in precocious myocardial infarction
}

\author{
A. L. Bahl \\ From the Department of Medicine, Willingdon Hospital, New Delhi, India
}

$A$ series of 45 patients who had a myocardial infarction before the age of 45 years has been studied and investigated for alterations of glucose tolerance, as shown by standard and prednisolone-primed glucose tolerance tests.

Abnormal responses to standard glucose tolerance tests and prednisolone-primed glucose tolerance tests were obtained in 75.5 per cent of patients with myocardial infarction, compared with 8.8 per cent of controls.

Sex, hypertension, obesity, and a positive family history did not affect the abnormalities of glucose tolerance.

Various views concerning these abnormalities in glucose metabolism are discussed.

Research during the past few years has shown that vascular complications do not necessarily follow a variable period of manifest diabetes mellitus but may antedate it by a few months or even years. Latent abnormalities of carbohydrate metabolism, detectable only with steroid-augmented glucose tolerance tests, have been reported in patients with unexplained neuritis and neuropathy (Ellenberg, 1963) and abnormalities in the small blood vessels and capillaries with a strong family history of diabetes mellitus (CameriniDávalos et al., 1963). During the past decade, abnormalities of glucose tolerance have also been shown in vascular disease, including myocardial infarction (Schrade, Boehle, and Biegler, 1960; Waddell and Field, 1960; Sowton, 1962; Wahlberg, 1962; Ostrander et al., 1965; Cohen and Shafrir, 1965; Lal et al., 1967; Lal, Bahl, and Bahl, I969).

The increased incidence of vascular disease and coronary heart disease in diabetics is well known (Root et al., 1939; Bell, I952; Bryfogle and Bradley, 1957; Bahl, 1968). On the other hand, studies on the incidence of the preclinical diabetic state in persons with precocious coronary heart disease are almost nonexistent, according to Herman and Gorlin (1965). Recently extensive research in carbohydrate metabolism has attracted wide attention. So many data have accumulated during the past decade that some of the fundamentals in the aetiology of diabetes mellitus have been

Received 20 January 1970. challenged. Even the definition of diabetes mellitus is in dispute. It is believed that diabetes starts at birth or even earlier as a Mendelian recessive trait (Joslin et al., 1959); this, when provoked by long-term stresses such as infection, pregnancy, and other factors, is eventually diagnosed as overt or clinical diabetes (Krall, 1965). Thus has emerged a new concept of the prediabetic state or preclinical diabetes, which may be an important factor in the aetiopathogenesis of coronary heart disease in young adults, and an inquiry into this may be rewarding (Banerjea, 1967). The present investigation is an effort in this direction.

\section{Subjects and methods}

Forty-five cases of proved myocardial infarction with onset up to 45 years of age and a similar number of age-matched controls formed the material for this study.

The diagnosis of myocardial infarction was based on the characteristic history of chest pain, an increase in serum aspartate aminotransferase, and unequivocal electrocardiographic abnormalities. Anterior myocardial infarct was considered to be present if $Q$ waves were detected in lead I and praecordial leads, with or without ST segment elevation and $T$ wave inversion. In inferior wall infarction, similar changes were present in leads II, III, and aVF. Such changes were seen in leads aVL and $V_{5}-6$ in patients with infarction of the lateral wall. Subendocardial myocardial infarction was diagnosed in the presence of persistent ST segment depression and $T$ wave inversion in the praecordial leads. In addition, reciprocal changes 
existed invariably during the acute phase of myocardial infarction.

None of these patients had a history of diabetes mellitus, and in all the fasting blood glucose was below I $10 \mathrm{mg}$./100 $\mathrm{ml}$. A standard glucose tolerance test was carried out at least two weeks after an attack of myocardial infarction. In 34 patients with a normal test, a prednisolone-primed glucose tolerance test was done after administration of Io mg. prednisolone $8 \frac{1}{2}$ and 2 hours before starting the test, and this latter test was not carried out until at least one week after the standard glucose tolerance test on the recommendations of Sanders (I96I).

The estimation of blood glucose was done by Nelson's modification of Somogy's method using venous blood (Nelson, I944). All patients received at least $300 \mathrm{~g}$. carbohydrate for at least 3 days before the test.

The controls consisted of convalescing patients with various illnesses, none of which was known to affect the glucose tolerance test. None of them received drugs such as corticosteroids, benzothiadiazine diuretics, etc. which affect glucose tolerance.

The controls were studied likewise using the standard and prednisolone-primed glucose tolerance tests, observing all the precautions mentioned above. The results were interpreted as follows (Bahl et al., 1969).

(I) Standard glucose tolerance test Frankly diabetic curve: blood glucose values within the first hour $160 \mathrm{mg}$./ $100 \mathrm{ml}$. or more, I $\frac{1}{2}$-hour values $140 \mathrm{mg}$. $/ 100 \mathrm{ml}$. or more, and 2 -hour values
$120 \mathrm{mg}$./100 ml. or more. Probably diabetic curve: 2-hour blood glucose estimation between I IO and I $19 \mathrm{mg}$./ $100 \mathrm{ml}$., or one of the other blood sugar values above the upper limits of normal (see below). Non-diabetic curves: blood glucose levels below $160 \mathrm{mg}$. $/ 100 \mathrm{ml}$. in the first hour, $1 \frac{1}{2}$-hour value less than $140 \mathrm{mg}$./ $100 \mathrm{ml}$., and 2-hour value less than I IO $\mathrm{mg}$. $/ 100 \mathrm{ml}$.

(2) Prednisolone-primed glucose tolerance test Abnormal response was indicated if the 2-hour blood glucose level was $140 \mathrm{mg}$./100 ml. or higher (Sanders, I96I).

\section{Observations}

Standard glucose tolerance test was carried out in 45 patients with myocardial infarction starting before 45 years of age and in an equal number of age-matched controls. Frankly diabetic curves were obtained in II $(24.4 \%)$ patients, and probably diabetic curves in another $2(4.4 \%)$. Prednisolone-primed glucose tolerance test was performed in the remaining 34 patients, and $2 \mathrm{I}(46.6 \%)$ showed abnormal responses.

In the 'control' subjects, frankly diabetic curves were seen in $3(6.6 \%)$, and I $(2 \cdot 2 \%)$ patient showed abnormal handling of glucose in the prednisolone-primed glucose tolerance test.

The mean blood glucose levels in precocious myocardial infarction and the controls

TABLE Mean blood glucose levels (mg./ $100 \mathrm{ml}$.) with standard deviation in precocious myocardial infarction and control cases

\begin{tabular}{|c|c|c|c|c|c|c|c|c|c|}
\hline & \multicolumn{5}{|c|}{ Standard glucose tolerance test } & \multicolumn{4}{|c|}{$\begin{array}{l}\text { Prednisolone-primed glucose } \\
\text { tolerance test }\end{array}$} \\
\hline & $\begin{array}{l}\text { No. } \\
\text { of } \\
\text { cases }\end{array}$ & o hr. & $\frac{1}{2} h r$ & $I_{2}^{\frac{1}{2}} h r$ & $2 h r$. & $\begin{array}{l}\text { No. } \\
\text { of } \\
\text { cases }\end{array}$ & o hr. & $I \frac{1}{2} h r$ & $2 h r$. \\
\hline $\begin{array}{l}\text { Precocious myocardial } \\
\text { infarction }\end{array}$ & 45 & $\begin{aligned} & 85 \cdot 1 \\
& \pm 12 \cdot 33\end{aligned}$ & $\begin{array}{l}152 \cdot 0 \\
\pm 36 \cdot 58\end{array}$ & $\begin{array}{l}135 \cdot 5 \\
\pm 15 \cdot 36\end{array}$ & $\begin{array}{r}110 \cdot 1 \\
\pm 16 \cdot 0\end{array}$ & 34 & $\begin{array}{c}168 \cdot 8 \\
\pm 12 \cdot 26\end{array}$ & $\begin{array}{l}150.1 \\
\pm 6.56\end{array}$ & $\begin{array}{r}138 \cdot 9 \\
\pm 10 \cdot 0\end{array}$ \\
\hline Controls & 45 & $\begin{aligned} & 75.8 \\
\pm & 28.68\end{aligned}$ & $\begin{array}{l}138.7 \\
\pm 45.87\end{array}$ & $\begin{array}{r}124 \cdot 2 \\
\pm 12 \cdot 45\end{array}$ & $\begin{aligned} & 97.2 \\
\pm & 14.04\end{aligned}$ & 42 & $\begin{array}{l}156.8 \\
\pm 9.43\end{array}$ & $\begin{array}{l}140 \cdot 3 \\
\pm 8.06\end{array}$ & $\begin{array}{l}126.0 \\
\pm 8.09\end{array}$ \\
\hline $\begin{array}{l}\text { Men with myocardial } \\
\text { infarction }\end{array}$ & $4 \mathrm{I}$ & 84.95 & $152 \cdot 3$ & 135.9 & $110 \cdot 2$ & 30 & 168.7 & $149 \cdot 9$ & 138.8 \\
\hline Control men & 37 & $\begin{aligned} & 76 \cdot 8 \\
&+23 \cdot 62\end{aligned}$ & $\begin{array}{r}140 \cdot 2 \\
\pm 25 \cdot 90\end{array}$ & $\begin{array}{c}123 \cdot 6 \\
\pm 19.45\end{array}$ & $\begin{array}{l}100 \cdot 0 \\
\pm 15 \cdot 18\end{array}$ & 33 & $\begin{array}{l}156 \cdot 9 \\
\pm 9 \cdot 34\end{array}$ & $\begin{array}{l}140 \cdot 3 \\
\pm 7 \cdot 22\end{array}$ & $\begin{array}{l}126.4 \\
\pm 8.06\end{array}$ \\
\hline $\begin{array}{l}\text { Women with myocardial } \\
\text { infarction }\end{array}$ & 4 & $88 \cdot 5$ & $148 \cdot 25$ & $132 \cdot 0$ & $108 \cdot 75$ & 4 & $169 \cdot 75$ & $151 \cdot 75$ & $139 \cdot 5$ \\
\hline Control women & 8 & $\begin{aligned} & 81 \cdot 875 \\
&+19 \cdot 69\end{aligned}$ & $\begin{array}{l}141 \cdot 75 \\
\pm 6 \cdot 58\end{array}$ & $\begin{array}{l}127 \cdot 375 \\
\pm 11 \cdot 51\end{array}$ & $\begin{array}{l}100 \cdot 0 \\
\pm 6.63\end{array}$ & 8 & $\begin{array}{l}156 \cdot 375 \\
\pm 10 \cdot 0\end{array}$ & $\begin{array}{l}140 \cdot 0 \\
\pm 9 \cdot 0\end{array}$ & $\begin{array}{l}124 \cdot 375 \\
\pm 1 I \cdot 45\end{array}$ \\
\hline $\begin{array}{l}\text { Myocardial infarction } \\
\text { patients with positive } \\
\text { family history }\end{array}$ & 7 & $\begin{array}{c}86 \cdot 6 \\
\pm 7 \cdot 62\end{array}$ & $\begin{array}{l}163.4 \\
\pm 35.69\end{array}$ & $\begin{array}{c}141 \cdot 4 \\
\pm 29 \cdot 94\end{array}$ & $\begin{array}{l}113.0 \\
\pm 15.22\end{array}$ & 6 & $\begin{array}{l}170.0 \\
\pm 7.65\end{array}$ & $\begin{array}{c}152 \cdot 2 \\
\pm 12.83\end{array}$ & $\begin{array}{l}140.7 \\
\pm 10.02\end{array}$ \\
\hline $\begin{array}{l}\text { Myocardial infarction } \\
\text { patients without } \\
\text { positive family history }\end{array}$ & 38 & $\begin{array}{r}79 \cdot 8 \\
\pm 31 \cdot 54\end{array}$ & $\begin{array}{c}149 \cdot 8 \\
\pm 37 \cdot 38\end{array}$ & $\begin{array}{c}134.4 \\
\pm 10 \cdot 49\end{array}$ & $\begin{array}{c}109 \cdot 8 \\
\pm 14 \cdot 40\end{array}$ & 28 & $\begin{array}{l}168 \cdot 6 \\
\pm 5 \cdot 39\end{array}$ & $\begin{array}{l}149 \cdot 7 \\
\pm 4 \cdot 76\end{array}$ & $\begin{array}{l}138 \cdot 5 \\
\pm 8 \cdot 83\end{array}$ \\
\hline $\begin{array}{l}\text { Obese patients with } \\
\text { myocardial infarction }\end{array}$ & II & $\begin{aligned} & 84.7 \\
& \pm 12.66\end{aligned}$ & $\begin{aligned} & 142 \cdot 9 \\
& \pm 17 \cdot 81\end{aligned}$ & $\begin{array}{c}129 \cdot 1 \\
\pm 23 \cdot 54\end{array}$ & $\begin{aligned} & 91 \cdot 0 \\
\pm & 15 \cdot 58\end{aligned}$ & II & $\begin{array}{l}167 \cdot 0 \\
\pm 6.65\end{array}$ & $\begin{array}{l}150.0 \\
\pm 6.07\end{array}$ & $\begin{array}{l}140 \cdot 2 \\
\pm 5 \cdot 36\end{array}$ \\
\hline $\begin{array}{l}\text { Non-obese patients with } \\
\text { myocardial infarction }\end{array}$ & 34 & $\begin{array}{c}85 \cdot 4 \\
\pm \mathrm{II} \cdot 02\end{array}$ & $\begin{array}{c}153.9 \\
\pm 44.82\end{array}$ & $\begin{array}{l}137.6 \\
\pm 10.06\end{array}$ & $\begin{array}{l}113.6 \\
\pm 16.40\end{array}$ & 23 & $\begin{array}{l}169 \cdot 7 \\
\pm 9.58\end{array}$ & $\begin{array}{l}149.9 \\
\pm 5.92\end{array}$ & $\begin{array}{l}138 \cdot 3 \\
\pm 9 \cdot 80\end{array}$ \\
\hline
\end{tabular}


are shown in the Table. Though all the mean blood glucose values were higher in patients with infarction, the differences were significant at the 5 per cent level of significance only for 0 -hour and $I \frac{1}{2}$-hour values in the case of the standard test and for $1 \frac{1}{2}$-hour and 2-hour values in the prednisolone-primed test.

There were only 4 women in the myocardial infarction group and 8 in the control group. Mean blood glucose levels in them are shown in the Table. The differences between the two groups were statistically insignificant for both the standard and prednisoloneprimed glucose tolerance tests. Of the 4 women with infarction, 3 showed higher blood glucose when the prednisolone-primed test was done and I was non-diabetic. In the control group only I of the 8 women had an abnormal curve when the prednisoloneprimed test was done, and the rest were nondiabetic.

A positive family history of diabetes could be elicited in only 7 patients with premature myocardial infarction; 2 of them showed abnormal responses with the prednisolone-primed test. The mean blood glucose levels in those with and without positive family history are shown in the Table. The differences between the two groups were statistically insignificant for both tests.

Obesity was associated in I I patients with precocious myocardial infarction, and of these 8 had abnormal curves on the prednisoloneprimed test. The mean blood glucose levels in obese and non-obese patients with infarction can be seen from the Table. Statistical analysis revealed the differences to be significant at the 5 per cent level of significance only for the 2-hour value after the standard test. In the prednisolone-primed test the mean blood glucose values were not significantly different.

Hypertension was associated in only 3 patients with premature myocardial infarction. Two of them were frankly diabetic, while the other patient showed higher 2-hour blood glucose in the prednisolone-primed test. The number of patients was too small for statistical analysis.

\section{Discussion}

The incidence of abnormal glucose tolerance as shown by both tests in a group of 45 patients with premature myocardial infarction was 75.5 per cent compared to 8.8 per cent in controls. Hatch et al. (1966) reported slight intolerance after these tests in 70 per cent of patients with coronary heart disease below 50 years of age. Tzagournis, Seidensticker, and Hamwi (1967) and Tzagournis et al. (1968) performed only the standard glucose tolerance test in groups of 25 and 45 patients with myocardial infarction below 40 years of age, and observed abnormalities of glucose tolerance in 40 per cent and 37.7 per cent, respectively, compared with 3.3 per cent of controls. Tzagournis et al. (1967, 1968) also reported that the mean blood glucose levels were higher in coronary heart disease than in controls. Herman and Gorlin (1965) reported that in a group of 77 patients with coronary artery disease (of these 13 were less than 40 years and 37 were less than 50 years) the fasting blood sugar level was abnormal in 13 patients. Of the remaining patients, intravenous glucose tolerance was performed in $\mathbf{4 2}$ patients, with $2 \mathrm{I}$ results in the diabetic range. Thus the total yield of abnormality in $55 \mathrm{sub}-$ jects completely studied was 62 per cent. Furthermore, 12 patients below 40 years of age had either the preclinical diabetic state or hyperlipidaemia or both.

Thus glucose intolerance appears to be an important risk factor in the genesis of precocious coronary heart disease. However, the incidence of diabetes in precocious coronary heart disease varies only from 3.5 per cent (Lukl, 1966) to 5.5 per cent (Banerjea, 1967) in different series with precocious coronary heart disease. The wide differences in the incidence are due to the fact that, (I) there is no unanimity of opinion regarding the age at which myocardial infarction is to be considered precocious, and (2) different tests are performed with variable diagnostic blood glucose levels to label a patient diabetic. One more aspect of this problem which needs our consideration is the fact that similar abnormalities of glucose tolerance have been shown in patients of all ages with myocardial infarction, and the incidence is variable from 35.7 per cent (Kimber and Phear, 1965) to 80.3 per cent (Lal et al., 1967) when both the standard and prednisolone-primed glucose tolerance tests are performed. But one would have expected a lesser incidence of such abnormalities of glucose handling in precocious myocardial infarction when it is realized that glucose intolerance increases with increasing age (Blumenthal and Berns, 1964). Thus, aberrations of glucose metabolism possibly play an even more significant role in the genesis of myocardial infarction in young patients.

Though the number of women in this series was small, no difference in the incidence of abnormal glucose tolerance in the two sexes was found. Obesity, hypertension, and positive family history of diabetes did not appear to affect glucose tolerance in premature myo- 
cardial infarction. Reaven et al. (1963) and Bahl et al. (1969) arrived at similar conclusions when cases of myocardial infarction in all age-groups were studied.

Various explanations for these abnormalities of glucose tolerance after myocardial infarction include temporary disturbances of vegetative brain centres and cardiac shock. Hepatic damage resulting from cardiac failure may be another factor causing glucose intolerance. Using lactic dehydrogenase (LDH) isoenzyme studies, Van der Helm and associates (1962) found that besides the appearance of 'heart' pattern of LDH isoenzyme distribution after recent myocardial infarction, some patients also had more intense isoenzyme activity in the $\mathrm{LDH}_{5}$ position, thus suggesting hepatic damage. This was subsequently confirmed by Aber et al. (1966) using bromsulphalein and serial LDH isoenzyme studies in ro patients with myocardial infarction. Other factors responsible for these alterations in glucose tolerance include increased production of epinephrine or epinephrine and glucocorticoids (Forssman, 1954), production of an insulin antagonist in cases with myocardial infarction (Vallance-Owen and Ashton, 1963), and chronic overnutrition (Hatch et al., 1966). Reaven et al. (1963) have suggested that diabetes mellitus and atherosclerosis are due to a more fundamental defect. The view of Sowton (1962) that cardiac infarction precipitates latent diabetes mellitus is generally accepted.

The pathogenesis of atherosclerosis in diabetes mellitus is not clearly understood. Various biochemical factors have been incriminated (Bradley and Partamian, 1965). It is also possible that this may be a part of specific diabetic microangiopathy which consists of thickening of capillary basement membrane due to deposition of PAS-positive material, with resulting interference in exchange of gases and metabolites (Herman and Gorlin, 1965). According to these authors such changes in the nutrient vessels of coronary arteries, though not thus far shown, may exist early in life and predispose to the premature changes that are seen.

Thanks are due to Brigadier H. B. Lal, Consultant in Medicine and Medical Superintendent, Willingdon Hospital, New Delhi, for his advice, constant encouragement, and permission to publish this paper; to Dr. A. N. Bahl, Biochemist, for valuable help in blood sugar estimations; and to Mr. V. C. Gupta, Statistical Assistant, Central Government Health Scheme, for help in the statistical analysis of the data.

\section{References}

Aber, C. P., Brunt, P. E., Jones, E. W., Richards, T. G., Short, A. H., and Bernstein, V. (I966). Liver function after myocardial infarction. Lancet, I, 1391 .

Bahl, A. L. (1968). Complications of diabetes mellitus. fournal of the Indian Medical Association, 50, 195. , Lal, H. B., Bhalla, A. S., Chugh, R. N., Mathur, K. P., and Bahl, A. N. (1969). Prediabetic state in myocardial infarction. Indian Heart fournal. In the press.

Banerjea, J. C. (1967). Editorial. Precocious ischemic heart disease. Indian Heart fournal, 19, 1.

Bell, E. T. (I952). A postmortem study of vascular disease in diabetes. Archives of Pathology, 53, 444.

Blumenthal, H. T., and Berns, A. W. (1964). Autoimmunity and aging. In Advances in Gerontological Research, pp. 289-341. Ed. by B. L. Strehler. Academic Press, New York

Bradley, R. F., and Partamian, J. O. (1965). Coronary heart disease in the diabetic patient. Medical Clinics of North America, 49, 1093.

Bryfogle, J. W., and Bradley, R. F. (I957). The vascular complications of diabetes mellitus. Diabetes, 6 , I59.

Camerini-Dávalos, R. A., Caulfield, J. B., Rees, S. B., Lozano-Castaneda, D., Naldjian, S., and Marble, A. (1963). Preliminary observations of subjects with prediabetes. Diabetes, 12, 508.

Cohen, A. M., and Shafrir, E. (1965). Carbohydrate metabolism in myocardial infarction. Behaviour of blood glucose and free fatty acids after glucose loading. Diabetes, 14, 84 .

Ellenberg, M. (1963). Diabetic complications without manifest diabetes. Fournal of the American Medical Association, 183, 926.

Forssman, O. (1954). Myocardial infarction and adrenal function. Acta Medica Scandinavica, Suppl. 296, I 50.

Hatch, F. T., Reissell, P. K., Poon-King, T. M. W., Canellos, G. P., Lees, R. S., and Hagopian, L. M. (1966). A study of coronary heart disease in young men. Circulation, 33, 679.

Herman, M. V., and Gorlin, R. (1965). Editorial. Premature coronary artery disease and preclinical diabetic state. American fournal of Medicine, 38, $48 \mathrm{r}$.

Joslin, E. P., Root, H. F., White, P., and Marble, A. (1959). The Treatment of Diabetes Mellitus, Ioth ed. Lea and Febiger, Philadelphia.

Kimber, R. J., and Phear, D. N. (1965). Glucose tolerance after myocardial infarction. Medical fournal of Australia, 1, 686.

Krall, L. P. (1965). When is diabetes? Medical Clinics of North America, 49, 893.

Lal, H. B., Bahl, A. L., and Bahl, A. N. (1969). Glucose tolerance in hypertension. Indian Heart fournal, 21, 55.

$\longrightarrow,-$ Chugh, R. N., and Bahl, A. N. (I967) Carbohydrate metabolism in myocardial infarction. Fournal of the Association of Physicians of India, 15, 267.

Lukl, P. (1966). Special features of myocardial infarction in the young adult. In Fifth World Congress of Cardiology Symposia, New Delhi, I966, p. 395.

Nelson, N. (1944). A photometric adaptation of the Somogyi method for the determination of glucose. fournal of Biochemical Chemistry, 153, 375.

Ostrander, L. D., Jr., Francis, T., Jr., Hayner, N. S., Kjelsberg, M. O., and Epstein, F. H. (1965). The relationship of cardiovascular disease to hyperglycemia. Annals of Internal Medicine, 62, Ir88.

Reaven, G., Calciano, A., Cody, R., Lucas, C., and Miller, R. (1963). Carbohydrate intolerance and 
hyperlipemia in patients with myocardial infarction without known diabetes mellitus. Fournal of Clinical Endocrinology and Metabolism, 23, ror3.

Root, H. F., Bland, E. F., Gordon, W. H., and White, P. D. (1939). Coronary atherosclerosis in diabetes mellitus. A postmortem study. Fournal of the American Medical Association, 113, 27.

Sanders, M. J. (1961). The effect of prednisolone on glucose tolerance in respect to age and family history of diabetes mellitus. Diabetes, Io, 4I.

Schrade, W., Boehle, E., and Biegler, R. (1960). Humoral changes in arteriosclerosis - investigations on lipids, fatty acids, ketone bodies, pyruvic acid, lactic acid, and glucose in the blood. Lancet, 2, 1409 .

Sowton, E. (1962). Cardiac infarction and glucosetolerance test. British Medical fournal, r, 84.

Tzagournis, M., Chiles, R., Ryan, J. M., and Skillman, T. G. (I968). Interrelationships of hyperinsulinism and hypertriglyceridemia in young patients with coronary heart disease. Circulation, 38, 1156.

, Seidensticker, J. F., and Hamwi, G. S. (1967). Serum insulin, carbohydrate and lipid abnormalities in patients with premature coronary heart disease. Annals of Internal Medicine, 67, 42 .

Vallance-Owen, J., and Ashton, W. L. (1963). Cardiac infarction and insulin antagonism. Lancet, $\mathbf{1}, 1226$.

Van der Helm, H. J., Zondag, H. A., Hartog, H. A., and Van der Kooi, M. W. (1962). Clinica Chimica Acta, 7, 540. Quoted by Aber et al. (I966).

Waddell, W. R., and Field, R. A. (1960). Carbohydrate metabolism in atherosclerosis. Metabolism, 9, 800 .

Wahlberg, F. (1962). Intravenous glucose tolerance test in atherosclerotic disease with special reference to obesity, hypertension, diabetic heredity and cholesterol values. Acta Medica Scandinavica, 17r, 